\title{
UPAYA PENERAPAN MODEL PEMBELAJARAN CARD SORT DALAM PENINGKATAN PRESTASI BELAJAR SOSIOLOGI KELAS X MIA 1 SMAN 5 BATANGHARI
}

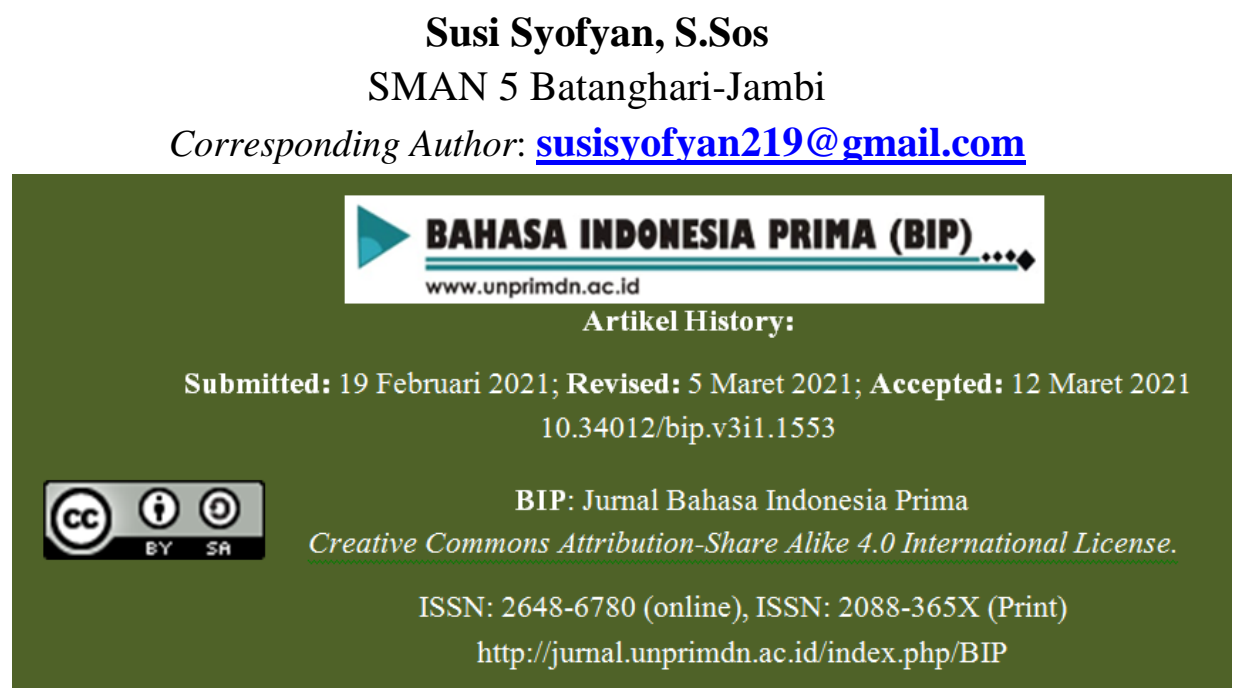

Abstrak-Berdasarkan temuan di lapangan menunjukkan bahwa pembelajaran Sosiologi mengalami kendala dalam proses pembelajarannya, terutama dalam cara seorang guru dalam memilih metode atau model pembelajaran yang variatif dan menarik. Dalam pembelajaran kurikulum 2013 lebih ditekankan kepada keaktifan siswa dengan siswa menjadi center atau pusat dalam proses pembelajaran. Hal ini dilakukan untuk membuat siswa aktif dan kreatif dalam usaha mengembangkan potensi siswa dan pada akhirnya mampu mencapai komptensi yang ditetapkan dalam kurikulum.Penelitian ini menggunakan penelitian tindakan (action research) sebanyak tiga putaran (siklus). Setiap siklus terdiri dari empat tahap, yaitu: perencanaan perencanaan, kegiatan/pengamatan, refleksi, dan revisi. Sasaran penelitian adalah Siswa kelas X Mia 1 SMAN 5 Batanghari Tahun Pelajaran 2018/2019 Semester Ganjil.Waktu pelaksanaan dari Bulan Agustus sampai Oktober 2018.Data yang diperoleh berupa hasil tes, lembar observasi kegiatan belajar mengajar.Dari hasil analisis didapatkan bahwa prestasi belajar siswa mengalami peningkatan dari siklus I sampai siklus III, yaitu siklus I (65,38\%), siklus II (76,92\%), dan sisklus III (92.30\%). Kesimpulan dari penelitian ini adalah pembelajaran dengan model pembelajaran Card Sort dapat berpengaruh positif terhadap prestasi belajar Siswa SMAN 5 Batanghari, khususnya kelas X Mia 1 serta model pembelajaran ini dapat digunakan sebagai salah satu alternative pembelajaran Sosiologi.

kata kunci : Sosiologi, Penerapan, Card Sort.

\section{A. Pendahuluan}

Pengembangan

pembelajaran merupakan suatu rangkaian kegiatan dalam merancang suatu pembelajaran yang harus dikembangkan guru sebagai bentuk pertanggung jawaban kegiatan profesinya kepada masyarakat, sejawat, dan peserta didik. Dalam pengembangan pembelajaran, guru harus menerjemahan prinsip-prinsip pedagogi dan pembelajaran dalam suatu perencanaan, dan kemudian merealisasikan perencanaan tersebut dalam bentuk pengalaman belajar peserta didik melalui 
kegiatan pembelajaran (Direktorat Pembinaan Sekolah Menengah Atas: 2015).

Mata pelajaran Sosiologi sebagai mata pelajaran IPS selama ini dianggap oleh siswa sebagai pelajaran yang membosankan karena dipenuhi konsep dan identik dengan dengan mata pelajaran hafalan.Untuk menyikapi permasalahan tersebut, guru harus memiliki beragam kemampuan yang dapat menunjang tugasnya agar tujuan pembelajaran dapat tercapai.Salah satu tuntutannya adalah memiliki kreasi dan daya inovatif, dalam mengembangkan model pembelajaran yang menarik bagi siswa.Namun, tidak hanya manarik tetapi yang utama adalah mampu meningkatkan prestasi belajar siswa.

Menciptakan model pembelajaran yang menarik bagi siswa tidaklah mudah, karena perlu kecermatan dari guru dalam menetukan dan menerapkan model pembelajaran yang sesuai dengan karakteristik materi pelajaran yang sesuai dengan karakteristik materi pelajaran yang akan diberikan sehingga tercipta proses belajar mengajar yang efektif. Oleh karena itu, guru harus menguasai beberapa jenis model pembelajaran agar proses belajar mengajar berjalan lancer.

Mutu pendidikan khususnya mata pelajaran Sosiologi, tentukan tidak lepas dari tiga factor, yaitu sekolah sebagai tempat terlaksanakan pendidikan, guru sebagai pelaksana, dan siswa sebagai peserta pendidikan. Ketiga faktor tersebut menjadi kurang berarti meskipun sudah disiapkan dengan baik, jika penyampaikan materi pelajaran menggunakan cara yang kurang tepat. Untuk mencapai tujuan pembelajaran, maka pada setiap akhir program pembelajaran dilakukan evaluasi yang salah satunya adalah peningkat prestasi belajar siswa.

Dewasa ini prestasi belajar siswa terutama dalam mata pelajaran Sosiologi khususnya di SMAN 5 Batanghari masih belum terlalu memuaskan. Hal tersebut dapat dilihat dari hasil ulangan harian siswa pada kompetensi dasar menjelaskan konsep dasar Sosiologi hanya mencapai nilai rata-rata 65 dan hanya 50\% siswa yang mencapai nilai 67 . Padahal idealnya minimal harus mencapai $100 \%$ siswa yang mendapat nilai 70.Kondisi tersebut disebutkan oleh kenyataan serhari-hari yang hanya menggunakan metode ceramah dan latihan soal secara individual serta contoh-contoh gambar.Apabila ditanya mengenai konsep sosiologi maka tidak dapat menjawab dengan tepat dan setiap tugas yang diberikan tidak selesai tepat waktu dengan alasan materi pelajarannya kurang menarik, memusingkan, dan sulit menghafal. Menyikapi hal tersebut, penulis sebagai Guru Sosiologi berusaha memperbaiki pembelajaran terutama yang berhubungan dengan materi Sosiologi dengan mengondisikan pembelajaran yang memudahkan, mengasyikkan, dan menyenangkan bagi siswa. Usaha tersebut akan diwujudkan dalam suatu penelitian tindakan kelas yang akan menerapkan model pembelajaran CARD SORT.

Model pembelajaran Card Sort menggunakan cara antara lain memberikan kartu indeks kepada masingmasing peserta didik, meminta peserta didik memilih kartu sesuai dengan kategori atau pertanyaan dan peserta didik yang telah selesai memilih kartu diberi kesempatan menyajikann sendiri kepada yang lain. Penerapan model pembelajaran Card Sort dianggap cocok 
dengan tingkat perkembangan siswa, terutama di SMAN 5 Batanghari.

Bertitik tolak dari latar belakang di atas, maka penulis merumuskan permasalahannya sebagai berikut.

1. Bagaimanakah peningkatan prestasi belajar siswa dengan diterapkannya metode Card Sort?

2. Bagaimanakah pengaruh metode Card Sort terhadap motuvasi belajar siswa?

Sesuai dengan permasalahan di atas, penelitian ini bertujuan :

1. Untuk mengtahui peningkatan prestasi belajar siswa diterapkannya setelah metode pembelajaran Card Sort.

2. Untuk mengetahui pengaruh metode Card Sort terhadap motivasi belajar siswa.

\section{Manfaat Penelitian}

Penulis mengharapkan dengan hasil penelitian ini dapat :

1. Memberikan informasi tentang metode pembelajaran yang sesuai dengan materi Sosiologi.

2. Meningkatkan motivasi pada pelajaran Sosiologi.

3. Mengembangkan metode pembelajaran yang sesuai dengan bidang studi Sosiologi.

\section{B. Kajian Teori}

\section{Model Pembelajaran Card Sort}

Yang dimaksud dengan model pembelajaran Card Sort adalah cara yang digunakan oleh guru untuk menyampaikan pelajaran kepada peserta didik. Model ini yaitu suatu strategi yang digunakan pendidik dengan maksud mengajak peserta didik untuk menemukan konsep dan fakta melalui klasifikasi materi yang dibahas dalam pembelajaran.

Sanaky (2006), strategi belajar memilah dan memilih kartu (Card Sort) adalah strategi dan metode belajar dengan cara memilah dan memilih kartu dengan tujuan untuk mengungkapkan daya ingat (recall) terhadap materi pelajaran yang telah dipelajari siswa. Sedangkan menurut silberman (2002) strategi belajar aktif tipe Card Sart adalah kegiatan kolaboratif yang bisa digunakan untuk mengajarkan konsep penggolongan sifat, fakta tentang suatu objek, atau mengulangi informasi gerakan fisik yang mengutamakan dapat membantu untuk memberi energi kepada kelas yang telah letih dan bosan.

Prosedur penerapan model pembelajaran Card Sort adalah sebagai berikut.

Langkah 1: Guru membagikan selembar kartu kepada setiap siswa dan pada kartu tersebut telah dituliskan suatu materi. Kartu tersebut berisi poin pengertian konsep.

Langkah 2: Guru menempelkan kartu konsep dasar di papan tulis.

Langkah 3 : Siswa akan berkelompok dalam satu poin pengertian konsep yang sama.

Langkah 3: Siswa diminta untuk menempelkan dipapan tulis bahasan yang ada dalam kartu mereka yang sesuai dengan konsep yang ditempel guru.

Langkah 4: Seorang siswa pemegang kartu dari masing-masing kelompok untuk menjelaskan dan sekaligus mengecek kerelevanan dari kartu yang mereka temple dengan konsep di papan tulis.

Langkah 5: Siswa yang salah mencari kelompok yang lebih tepat untuk poin pengertian konsep yang mereka miliki

Langkah 6: Guru mengecek ulang kebenaran hasil analisa siswa secara bersama-sama. 


\section{Prestasi Belajar Sosiologi}

Belajar dapat membawa suatu perubahan pada individu yang belajar.Perubahan ini merupakan pengalaman tingkah laku dari yang kurang baik menjadi baik. Pengalaman dalam belajar merupakan pengalaman yang dituju pada hasil yang akan dicapai siswa dalam proses belajar di sekolah. Menurut Poewodarminto (1991:768), prestasi belajar adalah hasil yang dicapai (dilakukan, dikerjakan). Dalam hal ini, prestasi belajar merupakan hasil pekerjaan, hasil penciptaan oleh seseorang yang diperoleh dengan ketelitian kerja serta perjuangan yang membutuhkan pikiran.

Sejalan dengan prestasi belajar, maka dapat diartikan bahwa prestasi belajar Sosiologi adalah nilai yang diperoleh siswa setelah melibatkan secara langsung/aktif seluruh potensi yang dimilikinya, baik aspek kognitif (pengetahuan), afektif (sikap), dan psikomotor (keterampilan) dalam proses belajar mengajar Sosiologi.

\section{Metode Penelitian}

Penelitian ini menggunakan pendekatan kualitatif, dalam bentuk penelitian tindakan kelas. Penelitian tindakan kelas adalah penelitian yang dilakukan oleh guru di dalam kelasnya sendiri melalui refleksi diri dengan tujuan untuk memperbaiki kinerja sebagai guru, sehingga hasil belajar siswa menjadi meningkat (Wardani2006 : 4).

Penelitian tindakan terdiri dari empat komponen pokok yang saling berhubungan secara procedural, sebagaimana disampaikan oleh Suharsimi Arikunto (2007 : 16), yaitu perencanaan, (2) pelaksanaan.
Menurut Oja dan Sumarjan (dalam Titik Sugiarti, 1997: 8) mengelompokkan penelitian tindakan menjadi empat macam, yaitu guru bertindak sebagai peneliti, penelitian tindakan kolaboratif.Simultan terintegratif, dan administrasi sosial eksperimental.

Dalam penelitian ini, peneliti tidak bekerjasama dengan siapapun.Kehadiran peneliti sebagai guru di kelas sebagai pengajar tetap dan dilakukan seperti biasa, sehingga siswa tidak tahu kalau diteliti. Dengan cara ini diharapkan didapat data yang seobjektif mungkin demi kevalidan data yang diperlukan.

\section{Hasil dan Pembahasan}

Analisis Data Penelitian Per Siklus

1. Siklus 1

a. Tahap perencanaan

Peneliti mempersiapkan perangkat mengajar dan membuat LDS 1 , soal tes 1 dan kartu soal yang dibutuhkan.

b. Tahap Kegiatan dan Pelaksanaan Pelaksanaan kegiatan belajar mengajar untuk siklus I, dilaksanakan pada tanggal 29 Agustus 2018 di kelas X Mia 1, dengan jumlah 26 siswa. Pembelajaran sesuai dengan rancangan pembelajaran yang telah dipersiapkan. Observasi dilaksanakan selama proses pembelajaran berlangsung.

Pada akhir proses belajar mengajar, siswa diberi tes 1 dengan tujuan untuk mengukur tingkat keberhasilan pelaksanaan belajar mengajar. 
Table 1.1. Rekapitulasi Hasil Tes pada Siklus 1

\begin{tabular}{|l|l|l|}
\hline No. & Uraian & Hasil Siklus 1 \\
\hline 1. & $\begin{array}{l}\text { Nilai rata }- \text { rata tes } \\
1\end{array}$ & 67,25 \\
\hline 2. & $\begin{array}{l}\text { Jumlah siswa yang } \\
\text { tuntas belajar }\end{array}$ & 17 \\
\hline 3. & $\begin{array}{l}\text { Persentase } \\
\text { ketuntasan belajar }\end{array}$ & 65,38 \\
\hline
\end{tabular}

Dari table di atas dapat dijelaskan bahwa dengan menerapkan model pembelajaran Card Sort diperoleh nilai rata - rata prestasi belajajr siswa adalah 67,25 dan ketuntasan belajar mencaoai $65,38 \%$ atau ada 17 siswa dari 26 siswa sudah tuntas belajar. Hasil tersebut menunjukkan bahwa pada siklus pertama secara klasikal siswa belum tuntas belajar, karena siswa yang memperoleh nilai $\geq 70$ hanya sebesar 65,38 lebih kecil dari persentase ketuntasan yang dikehendaki, yaitu sebesar $85 \%$. Hal ini disebabkan karena siswa masih belum mengerti apa yang dimaksudkan dan digunakannya model pembelajaran Card Sort ini.

\section{c. Refleksi}

Dari hasil pengamatan pelaksanaan kegiatan belajar mengajar diperoleh informasi sebagai berikut.

1) Guru masih kurang dalam sosialisasi media Card Sort.

2) Guru kurang motivasi dalam penyampaian tujuan pembelajaran.

3) Guru kurang baik dalam pengelolaan waktu.

4) Siswa kurang antusias selama pembelajaran berlangsung.

d. Revisi

1) Guru perlu mesosialisasikan media pembelajaran yang akan dilaksanakan.

2) Guru perlu lebih terampil dalam memotivasi siswa dan jelas Upaya Penerapan Model Pembelajaran Card Sort dalam Peningkatan Prestasi Belajar Sosiologi Kelas $X$ MIA 1 SMAN 5 Batanghari Batang Asai Kabupaten menyampaikan tujuan pembelajaran, dimana siswa diajak untuk terlibat langsung dalam setiap kegiatan yang akan dilakukan.

3) Guru perlu mendistribusikan waktu secara baik dengan menambahkan informasi-informasi yang dirasa perlu dan memberikan catatan.

4) Guru harus lebih terampil dan bersemangat dalam memotivasi siswa sehingga siswa lebih antusias.

2. Siklus II

a. Tahap Perencanaan

Pada tahap ini peneliti mempersiapkan perangkat pembelajaran yang mendukung terdiri dari rencana pelajaran 2, Lds, soal tes II, dan alat - alat pengajaran yang mendukung seperti kartu.

b. Tahap Pelaksanaan

Pelaksanaan kegiatan belajar mengajar untuk siklus II, dilaksanakan pada tanggal 12 September 2018 di kelas X Mia 1, dengan jumlah 26 siswa. Adapun proses belajar mengajar mengacu pada rencana pelajaran dengan memperhatikan revisi pada siklus 1 , sehingga kesalahan atau kekurangan pada siklus 1 tidak terulang lagi pada siklus II.

Pengamatan (observasi) dilaksanakan bersamaan dengan pelaksanaan belajar mengajar.

Pada akhir proses belajar mengajar, siswa diberi tes II dengan tujuan untuk mengetahui tingkat keberhasilan siswa dalam proses belajar mengajar yang telah dilakukan. Instrumen yang digunakan adalah tes II.Adapun data hasil penelitian pada siklus II adalah sebagai berikut. 
Tabel 1.2 Rekapitulasi Hasil Tes pada Siklus II

\begin{tabular}{|l|l|l|}
\hline No. & Uraian & $\begin{array}{l}\text { Hasil } \\
\text { Siklus }\end{array}$ \\
\hline 1. & Nilai rata - rata tes & 69,50 \\
\hline 2. & $\begin{array}{l}\text { Jumlah siswa yang } \\
\text { tuntas }\end{array}$ & 20 \\
\hline 3. & $\begin{array}{l}\text { Persentase } \\
\text { ketuntasan belajar }\end{array}$ & 76,92 \\
\hline
\end{tabular}

Dari table tersebut diperoleh nilai rata-rata prestasi belajar siswa adalah 69,50 dan ketuntasan belajar mencapai $76,92 \%$ atau ada 20 siswa dari 26 siswa sudah tuntas belajar. Hasil ini menunjukkan bahawa pada siklus II ini ketuntasan belajar secara klasikal telah mengalami peningkatan sedikit lebih baik, yaitu $11,54 \%$ dari siklus 1. Peningkatan hasil belajar siswa tersebut karena guru menginformasikan bahwa setiap akhir pelajaran akan selalu diakan tes, sehingga untuk pertemuan selanjutnya siswa lebih serius dan termotivasi untuk mengikuti pembelajaran. Dan juga karena sudah menjalani model pembelajaran ini pada siklus 1 , maka siswa sudah paham dan mengerti aturan main dalam penerapan model pembelajaran Card Sort ini.

\section{c. Refleksi}

Dalam pelaksanaan kegiatan belajar diperoleh informasi dari hasil pengamatan sebagai berikut.

1) Memotivasi siswa.

2) Membimbing siswa menemukan konsep.

3) Pengelolaan waktu

d. Revisi Rancangan

Dalam pelaksanaan kegiatan belajar pada siklus II ini masih terdapat kekurangan-kekurangan. Maka perlu adanya revisi untuk dilaksanakan pada siklus II antara lain :

1) Guru dalam memotivasi siswa hendaknya dapat membuat siswa lebih termotivasi selama proses belajar mengajar berlangsung.

2) Guru harus lebih dekat dengan siswa sehingga tidak ada perasaan takut dalam diri siswa baik untuk mengemukakan pendapat atau bertanya.

3) Guru harus lebih sabar dalam membimbing siswa merumuskan kesimpulan/menemukan konsep.

4) Guru harus mendistribudikan waktu secara baik sehingga kegiatan pembelajaran dapat berjalan sesuai dengan yang diharapkan.

\section{Siklus III}

a. Tahap Perencanaan

Peneliti mempersiapkan perangkat pembelajaran yang terdiri dari rencana pembelajaran 3 , Lds 3 , soal tes 3 , dan alat-alat pengajaran yang mendukung.

b. Tahap Kegiatan dan Pengamatan

Pelaksanaan kegiatan belajar mengajar untuk siklus III, dilaksanakan pada tanggal 03 Oktober 2018 di kelas X Mia 1 dengan jumlah 26 siswa. Dalam hal ini peneliti bertindak sebagai guru. Adapun proses belajar mengajar yang mengacu pada rencana pelajaran dengan memperhatikan refleksi dan revisi pada siklus II, sehingga kesalahan atau kekurangan pada siklus II tidak terulang lagi pada siklus III. Pengamatan (observasi) dilaksanakan bersamaan dengan pelaksanaan belajar mengajar. 
Pada proses belajar mengajar siswa diberi tes III dengan tujuan untuk mengetahui tingkat keberhasilan siswa dalam proses belajar mengajar yang telah dilakukan. Instrumen yang digunakan adalah tes III.

Tabel 1.3 Rekapitulasi Hasil Tes pada siklus III

\begin{tabular}{|l|l|l|}
\hline No. & Uraian & $\begin{array}{l}\text { Hasil } \\
\text { Siklus II }\end{array}$ \\
\hline 1. & $\begin{array}{l}\text { Nilai rata - rata } \\
\text { tes }\end{array}$ & 80,00 \\
\hline 2. & $\begin{array}{l}\text { Jumlah siswa } \\
\text { yang tuntas } \\
\text { belajar }\end{array}$ & 24 \\
\hline 3. & $\begin{array}{l}\text { Persentase } \\
\text { ketuntasan } \\
\text { belajar }\end{array}$ & $92,30 \%$ \\
\hline
\end{tabular}

Berdasarkan table di atas, diperoleh nilai rata - rata tes III sebesar 80,00 dan dari 26 siswa yang telah tuntas sebanyak 24 siswa dan 2 siswa belum mencapai ketuntasan belajar. Maka secara klasikal ketuntasan belajar yang telah tercapai sebasar 92,30\% (termasuk kategori tuntas). Hasil pada siklus III ini mengalami peningkatan lebih baik dari siklus II. Adanya peningkatan hasil belajar pada siklus III ini dipengaruhi oleh adanya peningkatan kemampuan guru dalam menerapkan belajar dengan model pembelajaran Card Sort, sehingga siswa menjadi lebih terbiasa dengan pembelajaran seperti ini sehingga lebih mudah dalam memahami materi yang telah diberikan.

c. Refleksi

Pada siklus 3 ini, hasil refleksi menunjukkan adanya peningkatan baik dalam proses pembelajaran maupun keaktifan para peserta didik menunjukkan kea rah yang lebih baik, Berdasarkan hasil tes dan pengamatan guru, ditemukan beberapa kemajuan yang terjadi pada siklus III ini, diantaranya:

- Proses pembelajaran yang dilakukan pada saat guru menerangkan dan melaksanakan pembelajaran Card Sort terlihat lebih efektif dan lebih efisien, karena para peserta didik juga ikut berpartisipasi dalam belajar bersama dan mampu mengidentifikasi topik permasalahan.

- Dibandingkan dengan siklus I dan II, selama proses belajar mengajar telah dilaksanakan dengan baik. Meskipun masih ada aspek yang belum sempurna, tetapi persentase pelaksanaannya untuk masingmasing aspek cukup baik.

- Berdasarkan data hasil pengamatan diketahui siswa sudah memahami pelaksanaan model pembelajaran Card Sort dan siswa aktif dalam pembelajaran.

d. Revisi Pelaksanaan

Pada siklus III guru telah menerapkan model pembelajaran Card Sort dengan baik dan dilihat dari aktivitas siswa serta hasil belajar siswa pelaksanaan proses belajar mengajar sudah berjalan dengan baik. Maka tidak diperlukan revisi terlalu banyak, tetapi yang perlu diperhatikan untuk tindakan selanjutnya adalah memaksimalkan dan mempertahankan apa yang telah ada dengan tujuan agar pada pelaksanaan proses belajar mengajar selanjutnya penerapan model pembelajaran Card Sort dapat meningkatkan proses belajar mengajar sehingga tujuan pembelajaran dapat tercapai. 


\section{E. Penutup}

1. Simpulan

Dari hasil kegiatan yang telah dilakukan selama tiga siklus, dan berdasarkan seluruh pembahasan serta analisa yang telah dilakukan dapat disimpulkan sebagai berikut.

a. Pembelajaran dengan model pembelajaran Card Sort memiliki dampak positif dalam meningkatkan prestasi belajar siswa yang ditandai dengan peningkatan ketuntasan belajar siswa dalam setiap siklus, yaitu siklus I $(65,38 \%)$, siklus II (76,92\%), dan siklus III (92,30\%).

b. Penerapan model pembelajaran Card Sort mempunyai pengaruh positif, yaitu dapat meningkatan motivasi belajar siswa yang ditunjukkan dengan rata-rata jawaban siswa hasil wawancara yang menyatakan bahwa siswa tertarik dan berminat dengan model pembelajaran ini, sehingga mereka menjadi termotivasi untuk belajar.

2. Saran

Dari hasil penelitian yang diperoleh dari uraian sebelumnya agar proses belajar mengajar Sosiologi lebih efektif dan lebih memberikan hasil yang optimal bagi siswa, maka disampaikan saran sebagai berikut.

a. Guru hendaknya mempertahankan mempergunakan pembelajaran dengan pendekatan scirntifik serta kontekstual di antaranya dengan menggunakan metode dan model yang bervariasi sehingga memungkinkan pembelajaran sangat interaktif, sehingga siswa mendapat pengalaman langsung guna menumbuhkan minat siswa dalam belajar. b. Apabila guru menggunakan model pembelajaran Card Sort maka harus mempersiapkan segala sesuatunya dengan cermat dan baik serta mempertimbangkan kelas yang akan digunakan, dan jam pelajaran yang akan digunakan. Hal ini harus diperhatikan supaya pembelajaran tidak mengganggu mata pelajaran yang lain.

c. Perlu adanya penelitian yang lebih lanjut, karena hasil penelitiam ini hanya dilakukan di Kelas X Mia 1 SMAN 5 Batanghari. Maka perlu penelitian lanjutan di kelas $\mathrm{X}$ lis SMAN 5 Batanghari.

\section{DAFTAR PUSTAKA}

Arikunto, Suharsimi \& Suhardjono \& Supardi. 2006. Penelitian Tindakan Kelas. Jakarta: Bumi Aksara.

Dahar, Ratna Willis. 1988. Teori-Teori Belajar. Jakarta: Dirjen Pendidikan Tinggi Depdikbud.

Depdibud. 2002. Pendekatan Konstektual. Jakarta: Balai Pustaka.

Uno, B, Hanzah. 2007, Model Pembelajaran, Menciptakan Belajar Mengajar yang Kreatif dan Efektif, Jakarta: Bumi Aksara.

Trianto, 2007. Model-Model Pembelajaran Inovatif Berorientasi Konstruktivistik, T.P.

Wetherington.H.C and W.H. Walt, Burton, 1986, Teknik-teknik Melajar dan Mengajar. (terjemahan) Bandung: Jemmars. 